\title{
VALUE RELEVANCE-EVIDENCE FROM FOOD INDUSTRY
}

Dušan Saković ${ }^{1}$, Milloš Ilić ${ }^{2}$

*Corresponding author E-mail: dusansakovic@yahoo.com

\begin{abstract}
A R T I C L E IN F O
A B S T R A C T

Review Article

The aim of the paper is to determine the correlation

Received: 08 May 2018 between the changes in the values of the selected analytical

Accepted: 16 June 2018 indicators, based on the financial statements and the change doi: 10.5937/ekoPolj1803099S

UDK 336:663/664 in the market value of companies, expressed through the value of the market value multipliers. The focus of research is on companies operating on the European markets within the food industry. The research methodology implies the

Keywords:

Value relevance, food industry, analytical indicators

JEL: G32, Q14

use of regression analysis where the market multipliers of the selected enterprises will be set as dependent variables, and the analytical indicators are proposed as independent variables. The expected results should indicate the existence of value-relevant information in the financial statements of companies from food industry, which will serve all stakeholders for more efficient decision-making that is related to this industry sector. Data used in the research are acquired from European equity markets.
\end{abstract}

(C) 2018 EA. All rights reserved.

\section{Introduction}

Modern business conditions include the need for making various business decisions in a dynamic environment. When business decisions are related to lending, mergers and acquisitions, strategic separation of companies, privatization and other similar transactions involving the exchange of parts or entire enterprises, managers most often rely on valuation models as a basis for deciding on the value of the company. Trends in practice speak in favor of the fact that there are more and more of these types of transactions and that there is a need to find out how changes in daily operations cause changes in the market value of the company. Value relevance of accounting information implies a close connection of balance information with the movement of the market value of companies. Starting from the analysis of fundamental valuation models such as discounting cash flow or dividend models, it can be concluded that the company's market value base stems from its long-term ability to generate positive cash flows and profits, reduce business risk and create conditions for continuous growth (Nissim, 2011).

1 Saković Dušan Ph.D, Accounting Department Deputy Director, MK Group d.o.o., Trg Marije Trandafil 7, Novi Sad. Mob: 060/64-33-092.E-mail: dusansakovic@yahoo.com

2 Ilić Miloš, M.Sc. Economics, Head of Client services Unit Erste Bank a.d., Bulever Oslobođenja 5, Novi Sad. Ph.D. candidate at Economic faculty of Subotica, Segedinski put 9-11, Subotica. Mob: 060/517-48-31. E-mail: milos.ilic@erstebank.rs 
In this context, as determinants of company's value we can recognize all activities that lead to such conditions and which are financially manifested through the balance sheets and analytical indicators that are value relevant.

The question arises: what are generally accepted analytical indicators that are said to be value relevant? And do they apply equally in different industries? Or how do they explain the value of the companies operating in the food industry? Analytical indicators based on accounting information are the basic tools for analyzing and planning business. The informative value of the accounting information contained in the analytical indicator determines its quality and usability in the decision-making processes. If we return to the fundamental valuation models, the value relevance would be linked to analytical growth, risk and profitability indicators as the basis for creating a new value.

The main goal of the empirical research is to present analytical indicators that are value relevant within the food industry sector. The aim is to demonstrate a statistically significant correlation between the movement in value of the selected analytical indicators and market value of the companies, on a sample of companies from the food industry sector.

Value relevance is being defined as the ability of information disclosed by financial statements to capture and summarize firm value (Sibel, 2013). Value relevance refers to the usefulness of using financial statements from the perspective of the owner of the capital and other interested parties who want to find out the value of the company (Sakovic, 2018). Value relevance implies the correlation between the accounting information disclosed in the financial statements (egg accounting data, cash flow indicators and other analytical indicators) and market values of company (market capitalization and other market indicators). Greater correlation implies greater value relevance of specific information. If there is no link between the balance sheet and income statement positions and the value of the company, there is no value relevance, and the financial statements in this case do not fulfill one of their basic purpose. Value relevance of accounting information varies depending on the development of institutional infrastructure and is usually more significant in countries with the higher degree of economic development (Ali, Hwang, 2000).

In financial theory, there are several interpretations of the meaning of value relevance, depending on the context of its use, the importance in determining the market price of shares and decisions on them.

One point of view analyses value relevance from the perspective of the use of accounting information in deciding on the purchase or sale of publicly available shares. According to this viewpoint, information is value relevant if it changes the overall information base on the market, or if traders actively use it on the market when making investment decisions (Collins, Maydew, Weiss, 1997). In doing so, traders are guided solely by publicly available accounting information from the balance sheet and income statement of the company (Ball, Brown, 1968). 
Another viewpoint where value relevance is viewed from the perspective of the valuation models, implies that accounting information is value relevant if it helps in predicting the values that are necessary in analysis of traditional valuation models (Chang, 1999). For example, accounting information is value relevant if it has the ability to anticipate future free cash flows or dividend payouts when it comes to the discounting cash flow or the discounting dividends model respectively (Brief, Zarowin, 1999).

The third interpretation of value relevance does not focus solely on accounting information and their ability to predict market values and market indicators. According to this understanding, value relevance refers to the ability of all types of indicators to capture and summarize all relevant information regardless of their source. This information can be derived from the financial statements, but also from other sources such as plans, specific reports, etc. (Francis, Schipper, 1999).

Another way of explaining the value relevance of accounting data derivates from the valuation models. According to Frankel and Liu (1998), the existence of correspondence of market value with an estimated intrinsic value of an enterprise by any valuation model indicates the existence of value-relevant information in the accounts of that company. Namely, in each valuation model there are certain determinants that determine the value. For example, in traditional yield methods these are free cash flows or dividend yields. In the cost method, this is the carrying amount of assets and liabilities. In multiplier models, these are the balance positions that create the multiplier. Regarding the multipliers model, specifically P/E and P/B models, Cheng and McNamara (2000), concluded that profitability rate and the book value of capital are value relevant

Authors Pervan and Bartulovic (2014) concluded that accounting information, i.e. book value and earnings are value relevant. They conducted research on the sample of companies from Southeast Europe. The analysis of regression and determination coefficients has shown that on the observed capital markets value relevance of book value is higher than value relevance of earnings.

Confirming the value relevance of information used in valuation models arises from the accuracy of the estimation of these models. If the result of the assessment of a model is a properly established value of the company, it is considered that the information which is used is value relevant because it has led to the correct intrinsic value. Consequently, the value relevance in this case does not only apply to accounting information, but also to all other involved in the creation of the value of the company.

Starting from the model of the market multipliers, Schreiner (2007) presents correlation between the P/E and EV/EBITDA multipliers and traditional yield models, in which way the author highlights which value-relevant information is dominant in multiplier models. Analyzing their mathematical connections (Richter 2005), the author concludes that there are similarities in the basic determinants of the presented models, that is, that the traditional yield and market models are based on the same fundamentals, which are lower business risk, opportunities for achieving growth and higher profitability. Richter concludes that market multipliers represent the mathematical alternative for traditional yield methods (2005). 
Table 1. Correlation-multipliers and yielding models

\begin{tabular}{|l|c|c|}
\hline & P/E & EV/EBITDA \\
\hline Method & Discounted dividend model & Discounted Cash Flow model \\
\hline $\begin{array}{l}\text { Model } \\
\text { formula }\end{array}$ & $\mathrm{V}_{\mathrm{t}}^{\text {equity }}=\sum_{\mathrm{i}=1}^{\infty} \frac{\mathrm{D}_{\mathrm{t}+\mathrm{i}}}{\left(1+\mathrm{r}_{\mathrm{t}+\mathrm{i}}^{\text {equity }}\right)}$ & $V_{t}^{\text {entity }}=\sum_{i=1}^{\infty} \frac{\left(F C F_{t+i}\right)}{\left(1+r^{\text {wacc }}\right)^{\mathrm{i}}}$ \\
\hline $\begin{array}{l}\text { Adjusted } \\
\text { formula }\end{array}$ & $V_{t}^{\text {equity }}=\frac{D_{t+i}}{r^{\text {equity }}-g^{D}}$ & $V_{t}^{\text {entity }}=\frac{F C F_{t+1}}{r^{\text {wacc }}-g^{F C F}}$ \\
\hline $\begin{array}{l}\text { Connection } \\
\text { with the } \\
\text { multiplier }\end{array}$ & $\frac{V_{t}^{\text {equity }}}{N P_{t}}=\frac{P R \times\left(1+g^{N p}\right)}{r^{\text {equity }}-g^{N p}}$ & $\frac{V_{t}^{\text {entity }}}{E B I T}=\frac{\left(1+g^{F C F}\right)(1-\text { tax rate }) \times\left(1-\frac{g^{F C F}}{R O I C_{t}}\right)}{r^{\text {wacc }}-g^{F C F}}$ \\
\hline
\end{tabular}

Source: Schreiner, 2007

Analysis of the joint determinants of traditional yield models and market multipliers shows that growth rate, risk and profitability are value relevant. This raises the question of what are the most representative analytical indicators of growth, risk and profitability and whether they have the explanatory power when analyzing the values of the companies from the food industry. Within the empirical research, using a financial analysis, standard analytical indicators were derived and tested for value relevance.

\section{Materials and methods}

The aim of the empirical research is to examine the correlation between the selected analytical indicators and the value of individual multipliers for companies operating within the food industry. The task is to determine a group of analytical indicators for which it can be said that significantly explain the value of the company expressed through the value of market multipliers. Methodological steps that shape empirical research include the following steps:

1. collecting financial statements of all companies from the sample,

2. conducting financial analysis, calculation and selection of analytical indicators,

3. segmenting selected analytical indicators into the categories of growth, risk and profitability,

4. calculation of $\mathrm{P} / \mathrm{E}$ and $\mathrm{EV} / \mathrm{EBITDA}$ multipliers for companies from the sample,

5. setting linear regression equations (models) where the multipliers are set as the dependent variables and the selected analytical indicators are set to be independent variables (according to the research of An, Bhojraj, 2010),

6. testing regression models and displaying results. 
To achieve the goals of empirical research a multiple linear regression analysis will be used. The linear model is calculated using the equation:

$$
y=a+b 1 x 1+\cdots+\varepsilon \dot{i}
$$

Where:

y- Company's multiplier

$\mathrm{x}$ - Analytical indicator

$\varepsilon$ - Model error

b- regression coefficient

Within the research, a series of regression analyzes were conducted to answer the questions how well a set of selected analytical indicators of a company can predict the value of individual multipliers. Each regression analysis refers to one multiplier of value and to the entire set of food industry companies. The aim was to find a model that is best adapted to data, that is, a model that contains only those analytical indicators that have an impact on the value of the multiplier (the optimal number of analytical indicators).

For data processing IBM SPSS 20 statistical software is used. A multiple gradual regression analysis is applied within the research. The contribution of each analytical indicators to the individual multipliers is tested and the regression model is chosen step by step. The aim was to find a combination of analytical indicators that have the highest degree of value relevance in relation to the tested multipliers. The coefficient of determination will show which part of the variance of the individual multipliers can be explained by the model.

The selected analytical indicators that will be tested with regression equations are grouped into three basic groups:

1. Analytical indicators of company's growth.

The growth dynamics is an important determinant of value when the company is evaluated by traditional valuation models, that is, a critical input for traditional discounting valuation models. The theoretical and practical correlation of the company's growth rate with its value does not indicate how the growth can be measured and which analytical indicators can be important for the calculation of the company's growth.

In professional literature, the most frequently used growth rate is based on changes in the most important financial indicators, such as:

- sales

- net income

- total assets, etc. 
2. Analytical indicators of risk

In traditional valuation models, the risk of investing in an enterprise (company risk) is expressed through a discount rate, which represents a measure of the expected return on an initial investment, by which future cash flows or dividends are discounted to the present value. The calculation of the overall risk of investing in the company is an integral part of almost all valuation models. In an empirical study, assumption is that the risk of an enterprise can be represented through the values of analytical indicators of financial risk. For this purpose, analytical indicators were selected:

- debt/total obligations

- leverage

- interest rate coverage.

\section{Analytical indicators of profitability}

Profitability of companies can be measured by profit margins or profitability indicators. Profit margins (rates) represent the ratio of a certain result, net profit, or upper result in income statement and most often sales revenue. Profitability of companies is expressed as the effectiveness of the use of invested capital (assets). The earning power is the best indicator of profitability. This indicator shows the ability of the given investment to discard some kind of yield from its use (Rodić, Lakićević, Vukelić, Andrić, 2011).

The most important profitability indicators are:

- return on assets-ROA

- return on equity-ROE.

The result of the empirical research should be analytical indicators of companies that are value relevant, i.e. for which the regression analysis has established that as a group statistically significant explain the values of individual multipliers.

The sample for the empirical research consists of companies operating in the food industry. The sample contains only companies listed on the European capital markets, for which there are publicly available data necessary for carrying out the survey. The sample includes all countries of the European continent.

The set research problem requires the collection of data from annual financial reports of the company, as well as data from the capital markets such as shares values, achieved sales prices of entire companies, market capitalization etc. The time frame for collected data is 2012-2016. The total number of companies collected in the initial sample is 315 , which totals 1,322 observations in the initial sample. After forming the initial sample, some companies were eliminated from the sample. Initially, the companies that have extreme market capitalization values have been eliminated, and after that companies that have not publicly disclosed all the necessary data for conducting the analysis. After all eliminations, the number of observations in the sample was reduced to 1.001. Descriptive sample statistics are shown in Table 2. The sources for collecting the necessary data are the international database Amadeus. 
Table 2: Descriptive statistics of the sample-Financial data

\begin{tabular}{|l|c|c|c|c|c|}
\hline In 000 euro & $\begin{array}{c}\text { Number of } \\
\text { observations }\end{array}$ & $\begin{array}{c}\text { Arithmetic } \\
\text { mean }\end{array}$ & Median & Min & Max \\
\hline Market capitalization & 1.001 & 1.119 .454 & 17.172 & 920 & 78.708 .144 \\
\hline Entity value & 1.001 & 1.324 .371 & 27.905 & 300 & 89.490 .028 \\
\hline Total assets & 1.001 & 932.135 & 39.014 & 3.990 & 48.027 .000 \\
\hline Net profit & 707 & 101.667 & 2.261 & - & 5.515 .000 \\
\hline Book value of capital & 1.001 & 386.470 & 20.264 & 654 & 22.566 .576 \\
\hline EBITDA & 807 & 119.566 & 3.036 & - & 9.140 .000 \\
\hline
\end{tabular}

Source: The authors calculation

Selection of the company was based on the classification according to the international classification of economic activities (NACE Rev.2-Classification of Economic Activities). Under this classification, companies are classified into different levels: industrial sectors, divisions, groups, classes and subclasses. A sample of empirical research consists of companies that have a sectoral label beginning with " 1 " and which includes the following groups of companies belonging to the food industry:

Table 3: Food sector groups

\begin{tabular}{|c|c|c|}
\hline Description & $\begin{array}{c}\text { Group of } \\
\text { companies } \\
\text { (3-digit } \\
\text { company code) }\end{array}$ & Sector \\
\hline Production of meat and meat products & 101 & \multirow{9}{*}{ Production-Food industry } \\
\hline Production of fish & 102 & \\
\hline Production of fruits and vegetables & 103 & \\
\hline Production of food fats and oils & 104 & \\
\hline Production of milk products & 105 & \\
\hline Production of mill products & 106 & \\
\hline Production of pasta & 107 & \\
\hline Production of other food products & 108 & \\
\hline Production of water, juice and other soft drinks & 110 & \\
\hline
\end{tabular}

Source: The authors presentation

\section{Results and discussion}

Pearson correlation was used to examine the relations of the $\mathrm{P} / \mathrm{E}$ ratio and the $\mathrm{EV} /$ EBITDA multiplier with the company's growth variables (assets, sales, net income), company risk (debt/liabilities, leverage, interest rate coverage) and profitability (ROE, ROA, Profit Margin). Test results are shown in the following table. 
Table 4: Correlation-Analytical indicators with multipliers

\begin{tabular}{|l|c|c|c|c|c|c|c|c|c|c|}
\hline \multirow{2}{*}{$\mathbf{P} / \mathbf{E}$} & \multicolumn{3}{|c|}{ Growth } & \multicolumn{3}{c|}{ Risk } & \multicolumn{3}{c|}{ Profit } \\
\cline { 2 - 12 } & Assets & Sales & $\begin{array}{c}\text { Net } \\
\text { income }\end{array}$ & $\begin{array}{c}\text { Debt/ Total } \\
\text { obligations }\end{array}$ & Leverage & $\begin{array}{c}\text { Interest } \\
\text { coverage }\end{array}$ & ROE & ROA & $\begin{array}{c}\text { Profit } \\
\text { margin }\end{array}$ & $\begin{array}{c}\text { EBITDA } \\
\text { margin }\end{array}$ \\
\hline $\begin{array}{l}\text { Pearson's } \\
\text { correlation }\end{array}$ & 0,06 & 0,52 & 0,17 & 0,10 & $-0,33$ & $-0,02$ & $-0,10$ & $-0,11$ & $-0,02$ & 0,01 \\
\hline Significance & 0,000 & 0,000 & 0,000 & 0,000 & 0,000 & 0,004 & 0,000 & 0,000 & 0,581 & 0,783 \\
\hline $\begin{array}{l}\text { No. } \\
\text { observations }\end{array}$ & 1.001 & 1.001 & 707 & 1.001 & 1.001 & 954 & 1.001 & 1.001 & 702 & 807 \\
\hline $\begin{array}{c}\text { EV/ } \\
\text { EBITDA }\end{array}$ & \multicolumn{7}{|c|}{} & \multicolumn{7}{|c|}{} & & & & \\
\hline $\begin{array}{l}\text { Pearson's } \\
\text { correlation }\end{array}$ & 0,05 & 0,59 & 0,01 & 0,09 & $-0,40$ & 0,04 & 0,19 & 0,10 & 0,13 & $-0,03$ \\
\hline Significance & 0,037 & 0,000 & 0,005 & 0,000 & 0,000 & 0,441 & 0,000 & 0,15 & 0,000 & 0,014 \\
\hline $\begin{array}{l}\text { No. } \\
\text { observations }\end{array}$ & 807 & 807 & 707 & 807 & 807 & 807 & 807 & 807 & 707 & 807 \\
\hline
\end{tabular}

Source: The authors calculation

Based on the results, it can be concluded that growth variables positively correlate with both multipliers and that the highest linkage is with variable income growth. Variables that describe risk correlate negatively with the $\mathrm{P} / \mathrm{E}$ multiplier, or mostly negatively when it comes to the EV/EBITDA multiplier. In this group, only the leverage variable is significant. Variables that describe profitability behave differently within groups. The thing they have in common is that connections are lower than is the case with other analytical indicators.

Figure 1: Correlation of analytical indicators with P/E and EV/EBITDA multiplier

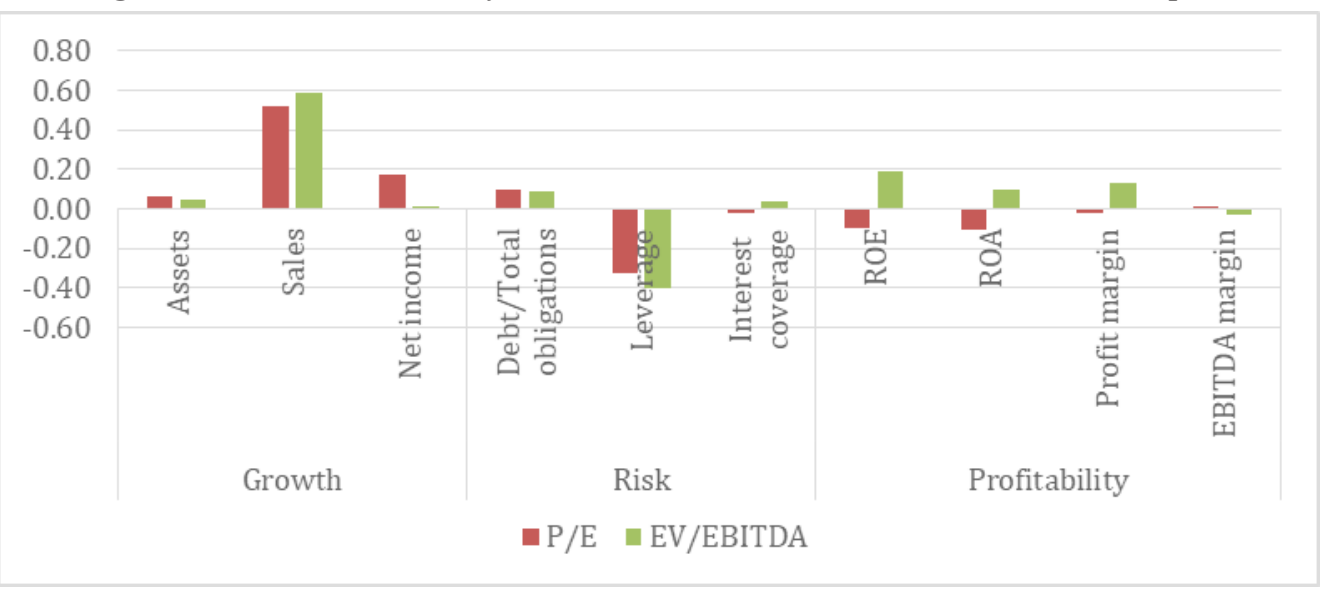

Source: The authors presentation

In accordance with the previously presented correlations, variables have been selected whose influence on multipliers is further investigated. These are the variables that best correlate with both multipliers. In this way, the variables that give the best contribution to the explanation of the value are selected for further analysis. The overall sample 
shows that best fitted variables are sales growth and leverage, with the note that for the EV/EBITDA multiplier a few analytical indicators of profitability are also significant. Descriptive statistics for variables of importance are given in table no. 5 .

Table 5: Descriptive statistics of independent variables P/E and EV/EBITDA

\begin{tabular}{|c|c|c|c|c|}
\hline & Min & Max & Arithmetic mean & $\begin{array}{c}\text { Standard } \\
\text { deviation }\end{array}$ \\
\hline P/E & 0,00 & 35,76 & 13,2353 & 9,2456 \\
\hline Sales growth & $-0,36$ & 0,38 & 0,0601 & 0,1308 \\
\hline Leverage & 0,00 & 1,12 & 0,3976 & 0,2787 \\
\hline EV/EBITDA & 0,01 & 27,56 & 9,0543 & 6,0423 \\
\hline Sales growth & $-0,35$ & 0,36 & 0,0587 & 0,1398 \\
\hline Leverage & 0,00 & 1,24 & 0,4776 & 0,2598 \\
\hline
\end{tabular}

Source: The authors calculation

In separate regression analyzes, it was investigated whether and to what extent changes in sales growth and leverage can predict the value of $\mathrm{P} / \mathrm{E}$ and EV/EBITDA multipliers. Multiple regression analysis was applied, in which independent variables were income growth and leverage, while dependent, variables $\mathrm{P} / \mathrm{E}$ and EV/EBITDA multipliers. There is no multicollinearity between independent variables, which was tested with Pearson's correlation.

The results of regression models indicate that the predictive set of independent variables describes $43.2 \%$ of the $\mathrm{P} / \mathrm{E}$ multiplier variance. Given the large number of cases involved in the analysis, the adjusted coefficient of determination is equal to $\mathrm{R}^{2}$ itself. In table no. 6 are presented the indicators of the regression model.

Table 6: P/E multiplier-indicators of the regression model

\begin{tabular}{|c|c|c|c|}
\hline Model & $\mathbf{R}$ & $\begin{array}{c}\text { Determination } \\
\text { coefficient }\left(\mathbf{R}^{2}\right)\end{array}$ & Adjusted $\mathbf{R}^{2}$ \\
\hline 1 & 0,657 & 0,432 & 0,432 \\
\hline
\end{tabular}

Source: The authors calculation

In table no. 7 are given individual contributions of the predictor variables included in the $\mathrm{P} / \mathrm{E}$ regression model. From the date presented it can be concluded that both independent variables predict the criterion statistically significant. This criterion is predicted in a positive direction by the sales growth, while the risk variable, leverage, predicts $\mathrm{P} / \mathrm{E}$ multiplier with the negative direction. The contribution of these two variables is almost identical, which can be seen based on standardized beta coefficients. 
Table 7: P/E multiplier-contribution of individual coefficients

\begin{tabular}{|c|c|c|c|c|c|}
\hline \multirow{2}{*}{ Model } & \multicolumn{2}{|c|}{$\begin{array}{c}\text { Non-standardized } \\
\text { coefficients }\end{array}$} & \multirow{2}{*}{$\begin{array}{c}\begin{array}{c}\text { Standardized } \\
\text { coefficients }\end{array} \\
\text { Beta }\end{array}$} & \multirow{2}{*}{$\mathbf{T}$} & \multirow[t]{2}{*}{ Significance } \\
\hline & B & $\begin{array}{l}\text { Stand. } \\
\text { error }\end{array}$ & & & \\
\hline (constant) & 19,23 & 0,219 & & 87,353 & 0,000 \\
\hline Sales growth & 29,36 & 0,849 & 0,418 & 34,355 & 0,000 \\
\hline Leverage & $-14,41$ & 0,417 & $-0,427$ & $-35,119$ & 0,000 \\
\hline
\end{tabular}

Source: The authors calculation

Regarding EV/EBITDA multiplier, regression model indicates that a set of independent variables explains a large percentage of variance of the dependent variable. More precisely, more than one half of the variance EV/EBITDA multiplier was explained by the set of variables income growth and leverage. In table no. 8, shown below, indicators of the regression model can be seen, as well as the percentage of explained variance.

Table 8: EV/EBITDA multiplier-indicators of the regression model

\begin{tabular}{|c|c|c|c|}
\hline Model & $\mathbf{R}$ & $\begin{array}{c}\text { Determination } \\
\left.\text { coefficient } \mathbf{( R}^{\mathbf{2}}\right)\end{array}$ & ${\text { Adjusted } \mathbf{R}^{\mathbf{2}}}^{\mathbf{2}}$ \\
\hline 1 & 0,712 & 0,507 & 0,507 \\
\hline
\end{tabular}

Source: The authors calculation

The contribution of individual independent variables to the EV / EBITDA multiplier on the total sample was also examined. The obtained results show that both variables, sales growth and leverage statistically significantly explain the dependent variable. Sales growth is driven by a higher contribution that is positively oriented. The leverage variable has a lower, but statistically significant contribution, which is negatively directed. Table no. 9 gives the individual contribution of all predictor variables included in the regression model.

Table 9: EV/EBITDA multiplier-contribution of individual coefficients

\begin{tabular}{|c|c|c|c|c|c|}
\hline \multirow[t]{2}{*}{ Model } & \multicolumn{2}{|c|}{$\begin{array}{c}\text { Non-standardized } \\
\text { coefficients }\end{array}$} & \multirow{2}{*}{$\begin{array}{c}\begin{array}{c}\text { Standardized } \\
\text { coefficients }\end{array} \\
\text { Beta }\end{array}$} & \multirow[t]{2}{*}{$\mathbf{T}$} & \multirow[t]{2}{*}{ Significance } \\
\hline & B & Stand. error & & & \\
\hline (constant) & 12,398 & 0,157 & & 73,744 & 0,000 \\
\hline Sales growth & 25,178 & 0,577 & 0,532 & 43,399 & 0,000 \\
\hline Leverage & $-7,945$ & 0,280 & $-0,332$ & $-28,088$ & 0,000 \\
\hline
\end{tabular}

Source: The authors calculation

The results obtained by empirical research are in line with the basic starting point of traditional valuation models, which also value the company based on the growth, risk and profitability of the company. The determination coefficients for both models tested confirm, in the case of the food industry, the correctness of the assumptions that are stated in the literature as drivers of value of companies (Pervan, Bartulović, 2014). The presented results related to the food industry represent a specific upgrade to the previous studies that dealt with this topic considering other industries (Brief, Zarowin P, 1999). 
What arises as a question and as a recommendation for future research is the role of specific value factors that are related to the food industry and whose involvement would result in further improvement of research results. Such factors could be in relation with production, sales, brand management, market conditions etc. Creating value in the food industry in any case relies primarily on internal generators, but new researches could summarize the existing internal factors from this research with the external economic trends related primarily to the food industry and then measure value relevance of all gathered information. This would enable all stakeholders to get wider image of value generators of the target company.

\section{Conclusion}

The results of the research on the value relevance of accounting information in the food industry indicate the existence of statistically significant links between changes in analytical indicators of growth and risk and the change in the value of market multipliers. Based on the measured coefficients of the determination, it is concluded that the analytical indicators of income growth and leverage are value relevant in relation to the $\mathrm{P} / \mathrm{E}$ and $\mathrm{EV} / \mathrm{EBITDA}$ multiplier. The results presented refer to the research of value relevance carried out at the level of all the companies from the sample, without their segmentation into subgroups of the food industry. Additional analysis covering only listed subgroups have very similar results previously presented. Consequently, it can be concluded that the results of the survey as the whole are related to each subgroup of the food industry with the same level of significance.

The presented results will enable all interested parties to understand better the drivers of value in the food industry and thus make more rational business decisions. These decisions are mainly linked with mergers, acquisitions and different types of corporative restructuring on the organized markets and with the non-listed companies as well. Trending in food industry indicate that there are more and more this kind of transactions, which gives more significance to the results of the research. Following the results of the research acquisition managers in food industry should track and analyze target company's sales growth potential and financial leverage when deciding on value.

\section{Conflict of interests}

The authors declare no conflict of interest.

\section{References}

1. Ali A., Hwang L.S. (2000). Country-Specific Factors Related to Financial Reporting and the Value Relevance of Accounting Data. Journal of Accounting Research 38, 2000, Chicago. USA

2. Amadeus (2016), data base. available at: https://amadeus.bvdinfo.com/ version-2017928/home.serv?product=AmadeusNeo 
3. An J., Bhojraj S., \& Ng D. (2010). Country. Industry and Idiosyncratic Components in Valuation Ratios. Working Paper. Korea Institute for International Economic Policy. Korea; Cornell University and the Wharton School at the University of Pennsylvania, USA

4. Ball R., Brown P. (1968). An Empirical Evaluation of Accounting Income Numbers. Journal of Accounting Research 6, 1968, p. 159-178. Chicago, USA

5. Brief R., Zarowin P. (1999). The Value Relevance of Dividends, Book Value and Earnings. Working Paper, New York University

6. Cheng C.S.A., McNamara R. (2000). The Valuation Accuracy of the Price-Earnings and Price-Book Benchmark Valuation Methods, Review of Quantitative Finance and Accounting 15, 2000, 349-370.

7. Chang J. (1999). The decline in value relevance of earnings and book values. Working paper, University of Pennsylvania, 1999.

8. Collins D.W., Maydew E.L., Weiss I.S. (1997). Changes in the value-relevance of earnings and book values over the past forty years. Journal of Accounting and Economics 24, 1997.

9. Francis J., Schipper K. (1999). Have Financial Statements Lost Their Relevance? Journal of Accounting Research 37, 1999.

10. Frankel R., Lee C.M.C. (1998): Accounting valuation, market expectation, and crosssectional stock returns. Journal of Accounting and Economics 25. Canadian Center of Science and Education, 1998.

11. Nissim D. (2011). Relative Valuation of U.S. Insurance Companies. Review of Accounting Studies, Forthcoming, Columbia Business School Research Paper, 2011, No. 12-3, available at: http://www.columbia.edu/ dn $75 /$ Relative $\% 20$ Valuation $\% 20$ of\%20U.S.\%20Insurance\%20Companies.pdf

12. Pervan I., Bartulović M., (2014). Value relevance of accounting information: evidence from South Eastern European countries. Economic Research-Ekonomska Istraživanja. Pula, Hrvatska 2014, Volume 27, Issue 1.181-190

13. Richter F., (2005). Mergers and Acquisitions: Investment analyse. Finanzierung und Prozessmanagement, Vahlen, Munich, Germany

14. Rodić J., Lakićević M., Vukelić G., Andrić M. (2011). Financial statement analysis. Proleter a.d., 2011, Bečej [In Serbian: Rodić J., Lakićević M., Vukelić G., Andrić M. (2011): Analiza finansijskih izveštaja]

15. Saković D. (2018). Analytical indicators of the peer group companies as the determinant of market multipliers model for valuation of entities. Doctoral dissertation. Economic faculty of Subotica. Serbia 2018. [In Serbian: Saković D. (2018). Analitički pokazatelji homogne grupe entiteta kao determinanta modela tržišnih multiplikatora za vrednovanje preduzeća]

16. Schreiner A. (2007). Equity Valuation Using Multiples: An Empirical Investigation. Doctoral dissertation of the University of St. Gallen, 2007, Wiesbaden

17. Sibel K., (2013). The Impact of IFRS on the Value Relevance of Accounting Information: Evidence from Turkish Firms. International Journal of Economics and Finance, Canadian Center of Science and Education 2013, Vol. 5, No. 4. 71-80. Canada. 